\title{
Digital Accounting Algorithms
}

\author{
Galina Krokhicheva, Iulia Mezentseva*, and Tang Zhen \\ Don State Technical University, Gagarin Square 1, Rostov-on-Don, Russia
}

\begin{abstract}
In the article, the authors explore some aspects of the organization of accounting processes in Russia. It is said that it is necessary to improve the existing accounting system in the country, as this requires the active development of digital technologies that widely cover the economy. The reorientation of the existing accounting system in the Russian Federation to the needs of the digital economy is possible through the widespread use of various digital accounting algorithms. The implementation of the proposed ideas can lead to a qualitative change in the organization of management and decision-making in all major areas.
\end{abstract}

\section{Introduction}

The current state of the economy can be characterized by three basic positions:

- information is the main economic resource;

- the Internet economy and the digital economy are the implementation of information capabilities at any level of management [1];

- innovative management is based on digital technical and economic resources. Among them, we can distinguish a system of methods for analyzing big data, evaluating options for the problem, and optimizing the solution to the problem. Ultimately, innovation management is carried out through the implementation of the digital economy paradigm $($ Economy $=$ Optimum + Equilibrium + Synergy [2]

The transition to the third paradigm of accounting and management development, called engineering, digital, etc., entails the need to create new accounting systems based on the use of digital technologies and platform solutions that provide online information management.

The current accounting systems no longer adequately meet the needs of modern business, lagging behind the rapid changes. Strategic aspects of the management of modern computerized enterprises integrated with the external environment require a qualitatively new information support, which serves as the basis for making strategic decisions.

Many scientists make a significant contribution to the formation of the digital accounting system. They, first of all, speak about the urgent need to introduce digital and behavioral mechanisms into practice instead of using manual systems focused on monitoring the performance of indicators according to reporting data.

At the same time, in practice, the transformation of the Russian accounting system is limited to convergence with international accounting and reporting standards, as well as

\footnotetext{
* Corresponding author: mezentseva.y.r@mail.ru
} 
point-by-point updating of the existing regulatory framework in response to emerging user requests. While making certain technical adjustments, the legislators, unfortunately, do not seriously raise the question of the need for a radical transformation of the Russian accounting system, which is objectively required by the conditions for the transition to the sixth technological order.

This leads to the need for constant theoretical study and improvement of digital accounting and management methods, their legislative consolidation, and also indicates an urgent need for their practical implementation. Achieving the global goals set by the state in digitalization, including the accounting system, will allow Russia not to remain "overboard" of global trends. [3, 4].

\section{Materials and methods}

Many scientific and practical schools have contributed to the formation of a digital accounting and management system. Among the researchers who are actively engaged in this problem are Kupenova Zh. [5], Parker J. [6], Bogataya I. [7], Vasilenko M. [8], Krokhicheva G. [9], Mezentseva Yu. [10], Odintsova T. [11], Spilnyuk I. [12], Tkach V. [13], Shumeyko M. [14]. Representatives of the scientific school under the leadership of Professor V. Tkach actively develop the ideas of the engineering theory of accounting, justifying the use in digital accounting of mathematical methods, matrices, algorithms, oriented graphs, engineering plans of accounts, engineering aggregated accounting transactions, mega-accounts, megabalance.

Digital accounting systems are built on the following principles, focused on the digital economy:

- design of a digital platform and operation of digital technologies equipped with a complex of digital mechanisms in the form of a system of megabalances;

- design of engineering tools that provide capital management of all types;

- management of economic situations and aggregated resource flows;

- formation of an engineering chart of accounts, in which the economic aggregates are megaccounts, a permanent record and a distributed register;

- use of aggregated accounting entries focused on property indicators;

- definition of a three-level security margin (active, neutral, passive) for the purpose of managing the reserve system;

- focus on determining the result of activities with a capital management system of all types;

- a generalized indicator of the organization's activity, the resulting synergy or anergism, focused on the use of all types of capital.

The digital accounting information platform, formed on the basis of the engineering chart of accounts, can be represented by the following elements:

- a system of mega

-calculations - - digital versatility,

- a system of algorithms (architectures, meters, initial and final operators, a set of iterations, aggregated accounting entries).

It will ensure the efficient operation of the enterprise by radically changing the system of accounting, control and analysis.

\section{Research results and discussion}

Algorithms have always been used in all spheres of activity, as they create a system of organized order, which is very important in the economy. 
Algorithmic analysis consists of two main parts: determining the essence of the problem, the so-called core, and identifying methods for designing a suitable algorithm based on the structure of the problem. These parts are interrelated and mutually dependent. When used with maximum efficiency, algorithmic ideas do not just provide solutions to clearly defined problems - they form a language for clearly expressing the questions underlying them [15].

The system of digital engineering algorithms is represented by the data of the figure 1 .

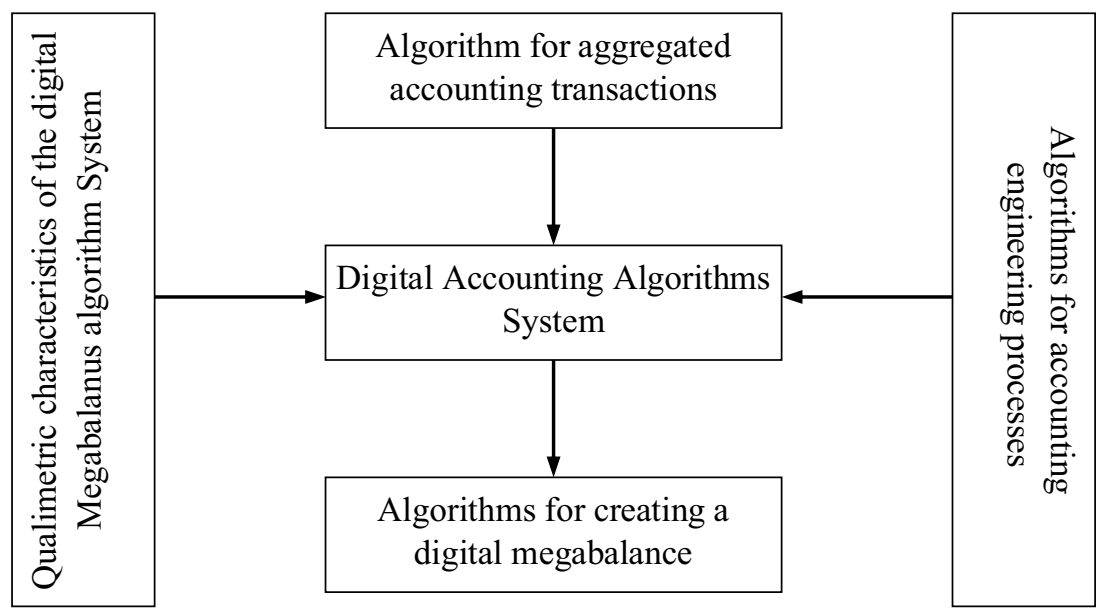

Fig. 1. Digital Accounting Algorithms System.

This is a regulated sequence of information processing and obtaining final data (initial operator, iterations (steps), final data describing the state of ownership), net assets in market valuation and net liabilities in fair value, financial risk zones (active, passive, neutral), safety margin and synergy or anergism of the operation of the enterprise and its structural divisions.

The basis of the system of accounting algorithms is a variety of megabalances. The use of digital mega balance sheets in the field of accounting, control and analysis is characterized by a wide variety of processes. Accounting and management of these processes is based on the system of qualimetric characteristics:

1.Digital qualimetry: principles, information space, integrated and evaluation processes, tools.

2. Technological qualimetry: initial operator, adjustment iterations; aggregated accounting and hypothetical transactions, final operator.

3. Result qualimetry: net assets and net liabilities in an adequate assessment, financial risk zone (active, passive, neutral), synergy effect, control of performance.

The algorithm of any aggregated accounting transaction has the following iterations:

1. Initial statement.

2. Economic objects.

3. The nature of the objects (active, passive).

4. The nature of the changes (increase, decrease).

5. The double entry rule.

The initial operator of the digital algorithm can be: the system of mega accounts, sections of the balance sheet, sections of the chart of accounts, etc.; the system of accounting balances; the system of strategic balances. steps:

The algorithm of aggregated accounting transactions is determined by the following 
- economic situation and its assessment;

- iterations of the aggregated transaction (from 2 to 16 steps, depending on the initial operator used);

- aggregated transaction (double entry rule);

- technical characteristics of an algorithmic program (computer type; computer; programming language; operating environment; digital platform; patent or certificate of registration of a computer program, digital accounting tools);

- result of use: net assets and net liabilities;

- control system: zero megabalances, accounting and control points, table of linking indicators, etc.

The algorithm of accounting engineering processes includes:

- adjustment processes related to the introduction of identified violations in economic activities and the preparation of the adjustment megabalance;

- digital processes of drawing up a specific megabalance and obtaining the result in book value or market value;

- hypothetical processes with obtaining a result in a fair assessment;

- transformation processes and so on.

Thus, digital accounting algorithms can have engineering characteristics:

- architecture;

- measuring system;

- structure of initial and final operators;

- iteration system;

- aggregated accounting transactions.

\section{Conclusion}

It can be concluded that the basis of digitalization of accounting, its ability to provide all the necessary information to interested users in real time is a system of digital accounting algorithms.

The proposals made by the authors imply further active development of the problem, the development of mechanisms for further integration, which will make analytical tools more integral and easier for users, while meeting both existing analytical needs and those that will appear in the near future. This problem can also be solved by using the digital accounting architecture.

\section{References}

1. The Digital Economy Foresight and Its Impact on the Russian Economic Environment Functioning: The Regions' Problems. Authors: G.E. Krokhicheva; Yu.R. Mezentseva; N.Yu. Izvarina; E.N. Sidorenko. Published: May 2020 in Proceedings of the International Conference on Economics, Management and Technologies (ICEMT) DOI: https://doi.org/10.2991/aebmr.k.200509.036 (2020)

2. Tkach V. I. The digital economy: Optimum, Equilibrium, synergism. Economy and ecology of territorial formations. V.2, no. 2. pp. 24-32. DOI: 10.23947/2413-1474-2-224-32 (2018)

3. The program "Digital Economy of the Russian Federation", approved by order of July 28, 2017 No. 1632 (2017)

4. Rastorguev S. V., Tyan Y. S. Digitalization of the Russian economy: trends, personnel, platforms, and challenges to the state. Monitoring of Public Opinion: Economic and 
Social Changes. No. 5. P. 136-161. https://doi.org/10.14515/monitoring.2019.5.08 (2019)

5. Zh. Kupenova, Digital economy and its role in accounting E3S Web of Conferences 159, 04032 BTSES-2020 https://doi.org/10.1051/e3sconf/202015904032 (2020)

6. Geoffrey G Parker, Marshall W Van Alstyne, Sangeet Paul Choudary. Platform Revolution. How Networked Markets Are Transforming the Economy and How to Make Them Work for You. W.W. Norton \& Company (2016)

7. Bogataya I. N., Evstafyeva E. M. The impact of digitalization of the economy on the development of accounting and analytical support for the management of a commercial organization. Accounting and statistics, No. 3 (55). URL: https://cyberleninka.ru/article/n/vliyanie-tsifrovizatsii-ekonomiki-na-razvitie-uchetnoanaliticheskogo-obespecheniya-upravleniya-kommercheskoy-organizatsiey (2019)

8. Vasilenko M. E., Ternovaya P. S. Digitalization in accounting and audit / / ANI: ekonomika i upravlenie. №3 (32). URL: https://cyberleninka.ru/article/n/tsifrovizatsiyav-buhgalterskom-uchete-i-audite (2020)

9. Digital accounting platform / J. R. Mezentseva [et al.] // E3S Web of Conferences. Vol. 224. - 8 p. - Article 03008. - (Topical Problems of Agriculture, Civil and Environmental Engineering (TPACEE 2020), Moscow, Russia, November 25-27, 2020). - URL: https://www.e3s-

conferences.org/articles/e3sconf/abs/2020/84/e3sconf_TPACEE2020_03008/e3sconf_T PACEE2020_03008.html (2020)

10. Mezentseva Y.R., Krokhicheva G.E., Kislaya I.A., Chukhrova O.V. (2021) Mega Accounts as Enlarged Economic Aggregates in Digital Accounting. In: Popkova E.G., Sergi B.S. (eds) Modern Global Economic System: Evolutional Development vs. Revolutionary Leap. ISC 2019. Lecture Notes in Networks and Systems, vol 198. Springer, Cham. https://doi.org/10.1007/978-3-030-69415-9_160 (2020)

11. T.M. Odintsova, O.V. Rura, Development of types, objects and methods of accounting in the digital economy and information society, St. Petersburg State Polytechnical University Journal. Economics, 11 (4) 120 - 131. DOI: 10.18721/JE.11409 (2018)

12. Iryna Spilnyk Accounting in the digital economy conditions. The Institute of Accounting, Control and Analysis in the Globalization Circumstances, V1-2, pp. 83-96 DOI: https://doi.org/10.35774/ibo2019.01.083 (2019)

13. Tkach Victor Ivanovich. Shchemelev Serge, Nikolaevich. Development of Digital (Engineering) Entity's Capital Management Frameworks // European Research Studies Journal Volume XX, Issue 3B, pp. 326 (2017)

14. M. Shumeyko, G. Sagamonova, E. Sagamonova, "Informational platform of the digital accounting", IOP Conference Series: Materials Science and Engineering, Vol. 698, p. 077047. DOI: https://doi.org/10.1088/1757-899X/698/7/077047 (2019)

15. Jon Kleinberg, Éva Tardos. Algorithm Design. Pearson/Addison-Wesley, (2006) 